\title{
Evaluation of Different Pinching Approaches on Seed Yield in Dhaincha
}

\author{
Hari Nayak $^{1 *}$, K. Kanaka Durga ${ }^{2}$, V. Bharathi ${ }^{2}$ and K. Keshavulu ${ }^{3}$ \\ ${ }^{1}$ Department of Seed Science and Technology, College of Agriculture, \\ Rajendranagar, Hyderabad, Telangana, India \\ ${ }^{2}$ Seed Research and Technology Centre, Rajendranagar, Hyderabad, Telangana, India \\ ${ }^{3}$ Telangana State Seed and Organic Certification, HACA Bhavan, Hyderabad, Telangana, India \\ *Corresponding author
}

A B S T R A C T

\begin{tabular}{|l|}
\hline Ke y w or d s \\
Evaluation, Yield, \\
Buds, \\
Micronutrient. \\
\hline Article Info \\
\hline Accepted: \\
10 September 2017 \\
Available Online: \\
10 October 2017 \\
\hline \hline
\end{tabular}

Studies on influence of pinching/suppression of terminal buds and foliar nutrition in dhaincha revealed that pods plant ${ }^{-1}$, seed yield plant $^{-1}$ and seed yield ha ${ }^{-1}$ was significantly influenced by both pinching and foliar sprays. The per cent increase in seed yield noticed with pinching was $15.38 \%$ over control and 7.70\% over cycocel spray @ 75 ppm. Among different foliar applications, maximum seed yield ha ${ }^{-1}\left(25.27 \mathrm{q} \mathrm{ha}^{-1}\right)$ was recorded with foliar spray with micronutrient mixture $\mathrm{ZnSO}_{4} 0.5 \%$ + Boric acid $0.3 \%$ followed by foliar spray with NAA 40 ppm (23.35 q ha $\left.{ }^{-1}\right)$. Among the interaction effects, spray of cycocel @ $75 \mathrm{ppm}+$ foliar application of micronutrient mixture $\mathrm{ZnSO}_{4} 0.5 \%+$ Boric acid $0.3 \%$ recorded maximum seed yield $\left(27.98 \mathrm{q} \mathrm{ha}^{-1}\right)$ and it was significantly different from other foliar sprays involving the same main treatment i.e. foliar spray with DAP $2 \%\left(24.19 \mathrm{q}^{-1}\right)$, foliar spray with DAP $2 \%+$ micronutrient mixture $(\mathrm{Zn}+\mathrm{B})+\mathrm{NAA}\left(18.72 \mathrm{q} \mathrm{ha}^{-1}\right)$ and control $\left(20.89 \mathrm{q}^{-1}\right)$.

\section{Introduction}

Green manuring is an age old practice of farming for maintaining soil fertility. However, the advent of green revolution has not only increased chemical fertilizer consumption but also marginalized the use of green manures in intensive cropping systems and is evident from the declining area under green manure crops over time. In 2004-05, green manure crops are cultivated on $3.57 \mathrm{~m}$ ha area (FAI, 2007-08). Dhaincha (Sesbania aculeata) is the most important green manure crop for in-situ incorporation in rice based cropping systems. Further, dhaincha cultivation is promising even under saline soils, ill drained soils and areas which receive heavy rainfall (Parlawar et al., 2003). The major constraint for dhaincha cultivation is the lack of availability of adequate quantity of quality seeds at appropriate time at reasonable price for small holding farmers or marginal farmers. Dhaincha seed production is mainly concentrated in peninsular India and by the time its seed reaches South India, the prices rise beyond purchase of seed and seed quality is not ensured. The protein rich dhaincha seed as an animal feed (Hossain et al., 2001) also demands production of more seed. Off late, quality seed production of dhaincha is under meager importance in spite of huge demand from farmers and less expertise was carried 
out in this area. Keeping in view, a study was carried out with an objective to study the influence of nipping or pinching of terminal buds on quality seed production and to find out the impact of foliar spray of DAP and micronutrients on quality seed production.

\section{Materials and Methods}

The present experiment was laid out in a split plot design in kharif, 2015 with pinching as main treatments and foliar sprays as sub treatments. There are three different levels of main treatments (with pinching at 20 DAS, without pinching and spray of cycocel @ 75 ppm at peak flowering stage) and five different levels of sub treatments (foliar spray with DAP @ 2\%, foliar spray with MN Mixture $\left(\mathrm{ZnSO}_{4} @ 0.5 \%\right.$ + Boric acid @ $0.3 \%$, foliar spray with NAA 40 ppm, foliar spray with DAP @ 2\% + MN Mixture (Zn + B) + NAA) and control. The experiment was conducted with three replications. Recommended dose of fertilizers were applied to raise a healthy crop. Seeds were dibbled to a depth of 3-4 $\mathrm{cm}$ by adopting a spacing of $60 \times 20 \mathrm{~cm}$ in a plot size of 24.75 $\mathrm{m}^{2}$ (15 rows of $2.75 \mathrm{~m}$ length each). Pre emergence application of Pendimethalin @ $1.25 \mathrm{~kg}$ acre $^{-1}$ was carried out immediately after sowing within one day before the soil gets dried. Further post emergence spraying with pursuit @ $1 \mathrm{ml} \mathrm{l}^{-1}$ at 20 to 25 DAS was taken up for the control of broad leaved weeds. Weeding was done manually at 15 and 45 DAS to keep the plot free from weeds.

Harvesting was done when the maturity symptoms were observed. Plot wise threshing and cleaning was done and seed yield was recorded after thorough drying and is expressed in $\mathrm{kg} \mathrm{ha}^{-1}$. Yield obtained from sample plants were also added to respective treatment yield. Data was recorded on the following observations: number of pods plant ${ }^{1}$, pod length $(\mathrm{cm})$, number of seeds pod ${ }^{-1}$, pod yield plant $^{-1}(\mathrm{~g})$, seed yield plant $^{-1}(\mathrm{~g})$, seed yield $\mathrm{ha}^{-1}(\mathrm{q})$, seed recovery (\%) and 100 seed weight $(\mathrm{g})$. The data was statistically analyzed duly following the analysis of variance technique for split plot design.

\section{Results and Discussion}

Analysis of the data as influenced by pinching and foliar nutrition revealed that pods plant ${ }^{-1}$, seed yield plant ${ }^{-1}$ and seed yield $\mathrm{ha}^{-1}$ was significantly influenced by both pinching and foliar sprays (Tables 1 and 2). Pod length, pod yield plant $^{-1}$ and seed recovery percentage was not influenced by both pinching and foliar applications. Further, 100 seed weight of the harvested produce obtained from first picking of the dhaincha crop was significantly influenced by pinching and cycocel treatment. However, the differences due to foliar nutrition were found non-significant.

Scrutiny of data on per cent seed recovery (Table 2) revealed that it was neither influenced by pinching/cycocel treatment nor by different foliar nutritions.

\section{Number of pods plant ${ }^{-1}$}

Highest number of pods plant ${ }^{-1}$ was recorded with pinching (28.2) and it was significantly higher than without pinching (22.0). Though dhaincha crop exhibited reduction in pods plant $^{-1}$ (24.7) with the spray of cycocel @ 75 ppm, it was statistically on par with pinching and without pinching treatments (Fig. 1). The removal of terminal buds directly by pinching and indirectly by spraying of chemicals contributed to increased number of pods plant $^{-1}$. Maximum increase in pod number over control was observed in pinched plants $(28.18 \%)$ followed by spray of cycocel (12.27\%). Results of the present experiment signify enhanced performance due to pinching and cycocel as they reduced plant height and increased number of branches as compared to 
control. The effectiveness of pinching may probably be due to the change induced in the rate of cell division in the meristematic region (Ahmad et al., 2007) thereby reducing the plant height promoting the development of increased number of healthy branches and flowers (Pathania et al., 2000) resulting in increase in the pod number. Further, the effectiveness of chemicals on pod production might be due to their retarding effect on apical growth, which in turn encouraged side branches (Ahmad et al., 2007).

Among foliar applications, foliar spray with micronutrient mixture $\left(\mathrm{ZnSO}_{4} 0.5 \%+\right.$ Boric acid $0.3 \%$ ) significantly recorded higher number of pods plant ${ }^{-1}$ (27.2) and it was significantly superior to foliar spray of DAP $2 \%+$ micronutrient mixture $(\mathrm{Zn}+\mathrm{B})+\mathrm{NAA}$ (24.5) and foliar spray with DAP 2\% (22.7).

The significant increase in number of pods with foliar application of zinc and boron could be attributed to increase in the number of branches plant ${ }^{-1}$. These micronutrients play an important role in various physiological and biochemical processes and contributes to the growth of the meristematic regions (Cakmak et al., 2000) thereby enhancing growth of plants in green gram (Elamathi and Pradeep, 2007). Boron plays an important role in cell division, cell differentiation, development, calcium utilization, translocation of photosynthates and growth regulators from source to sink, which in turn helps in maintaining higher leaf area, leaf area index and higher number of pods and pod weight plant $^{-1}$ (Kalyani et al., 1993). Further, boron plays an important role in preventing flower and pod drop, thereby retaining higher number of flowers and pods plant $^{-1}$ (Seifinadergholi et al., 2011). Similarly, the retention of flowers and pods can be increased by either foliar application of nutrients or plant growth regulators as reported by Sharma and Dey (1986) in green gram.
Among the interaction effects, pinching of the dhaincha crop in combination with foliar spray of micronutrient mixture $\left(\mathrm{ZnSO}_{4} 0.5 \%\right.$. + Boric acid $(0.3 \%)$ recorded maximum pods plant $^{-1}$ (31.2) and it was significantly different from pinching and foliar spray with DAP $2 \%$ (25.6) and pinching + foliar spray with DAP $2 \%+$ micronutrient mixture $(\mathrm{Zn}+\mathrm{B})+\mathrm{NAA}$ (26.0). The difference in pod number may be attributed to better utilization of resources from soil (Ajay Kumar, 2014).

\section{Pod length (cm)}

Though dhaincha crop recorded maximum pod length with spray of cycocel @ 75 ppm $(24.2 \mathrm{~cm})$, it was statistically on par with pinching $(23.7 \mathrm{~cm})$ and without pinching $(24.1 \mathrm{~cm})$ treatments indicating that mechanical pinching and use of cycocel had no significant impact on improving the length of the pod. These results are in contrary with the finding of Reddy et al., (2009) who reported significant increase in pod length in cowpea.

Pod length was maximum with foliar spray with NAA $40 \mathrm{ppm}(24.3 \mathrm{~cm})$ and was statistically on par with other three foliar spays and control indicating that spray of NAA@40 ppm exhibited numerical increase in pod length as compared to the control and other foliar applications. These results are in agreement with the findings of Ganiger et al., 2002 and Ajay Kumar et al., (2014).

Interaction effect of pod length of dhaincha crop as influenced by pinching and foliar applications revealed that spray of cycocel in combination with foliar application of micronutrient mixture $\left(\mathrm{ZnSO}_{4} 0.5 \%+\right.$ Boric acid $0.3 \%$ ) and spray of cycocel in combination with foliar application of NAA $40 \mathrm{ppm}$ recorded maximum pod length of $24.5 \mathrm{~cm}$ and was significantly different from 
pinching + foliar spray with micronutrient mixture $\left(\mathrm{ZnSO}_{4} 0.5 \%+\right.$ Boric acid $\left.0.3 \%\right)$ $(22.9 \mathrm{~cm})$ and without pinching + foliar spray with DAP $2 \%+$ micronutrient mixture $(\mathrm{Zn}+$ B) + NAA $(23.3 \mathrm{~cm})$.

\section{Number of seeds pod $^{-1}$}

Maximum number of seeds pod ${ }^{-1}$ was recorded with foliar spray of cycocel @ 75 ppm (34.6) and it was significantly different from pinching (33.0). Though dhaincha crop exhibited reduction in number of seeds pod $^{-1}$ (34.1) without pinching treatment, it was statistically on par with pinching and cycocel spray @ 75 ppm. These results are in agreement with the findings of Pourmohammad et al., (2014) who reported significant increase in seed number due to foliar spray with cycocel in rapeseed. However, Tripathi et al., (2013) reported that different topping practices in sunhemp did not exert any significant influence on number of seeds pod $^{-1}$ and test weight.

Among the sub treatments, foliar spray with NAA 40 ppm (34.2) and DAP 2\% (34.2) recorded significantly maximum seeds pod $^{-1}$ and was at par with the other treatments namely foliar spray with micronutrient mixture $\left(\mathrm{ZnSO}_{4} 0.5 \%+\right.$ Boric acid $\left.0.3 \%\right)$ (33.8), foliar spray with DAP $2 \%+$ micronutrient mixture ( $\mathrm{Zn}+\mathrm{B}+\mathrm{NAA})$ (33.6) and control (33.9). Similar increase in seeds $\operatorname{pod}^{-1}$ due to application of NAA (50 ppm) in cowpea was also reported (Ganiger et al., 2002 and Jayaram and Ramaiah, 1980).

Interaction effect of seeds pod $^{-1}$ as influenced by pinching and foliar sprays indicated that cycocel spray @ 75 ppm along with foliar application of NAA @ 40 ppm recorded maximum seeds $\operatorname{pod}^{-1}$ (35.5) and it was significantly different from foliar nutrition with DAP $2 \%+$ micronutrient mixture $(\mathrm{Zn}+$ B) + NAA of the same main treatment (33.8) and with pinching + foliar spray with DAP $2 \%$ (33.2), with pinching + foliar spray with micronutrient mixture $\left(\mathrm{ZnSO}_{4} 0.5 \%+\right.$ Boric acid $0.3 \%$ ) (31.9), with pinching + foliar spray with DAP $2 \%+$ micronutrient mixture $(\mathrm{Zn}+$ B) + NAA (33.4), with pinching + without foliar nutrition (33.0). The use of growth regulators is one of the potent factors for improving the growth of the crop, flower and pod setting, seed yield and quality.

The growth rate of plants are greatly influenced by the environment and growth substances, including exogenously applied growth regulators (Raghava et al., 1996) which in turn stimulate growth, flower initiation and pod setting of pulse crops (Devi et al., 2011). Improvement in growth characters in green gram by growth regulators application have been reported by Parmar et al., (2012).

\section{Pod yield plant ${ }^{-1}(\mathrm{~g})$}

Pinching of the terminal buds though recorded maximum pod yield plant ${ }^{-1}$ (289.14 g) it was statistically on par with without pinching treatment $(251.90 \mathrm{~g})$ and spray of cycocel @ 75 ppm (243.20 g).

Among the different foliar applications, foliar spray with NAA $40 \mathrm{ppm}$ has recorded significantly higher pod yield plant $^{-1}$ (266.37 g) and it was numerically superior over control (264.15 g), foliar spray with micronutrient mixture $\mathrm{ZnSO}_{4} 0.5 \%$ + Boric acid $0.3 \%$, (263.86 g), foliar spray with DAP $2 \%(261.88 \mathrm{~g})$ and foliar spray with DAP 2\% + micronutrient mixture $(\mathrm{Zn}+\mathrm{B})+\mathrm{NAA}$ $(250.81 \mathrm{~g})$, indicating that spray of secondary nutrients, micronutrients and growth promoting substances did not have any significant impact on enhancing pod yield plant $^{-1}$ 
Table.1 Influence of pinching/cycocel and foliar nutrition on yield components of dhaincha during Kharif, 2015-16

\begin{tabular}{|c|c|c|c|c|c|c|c|c|c|c|c|c|c|c|c|c|}
\hline \multirow[t]{2}{*}{ Treatments } & \multicolumn{4}{|c|}{ Number of pods plant $^{-1}$} & \multicolumn{4}{|c|}{ Pod length $(\mathrm{cm})$} & \multicolumn{4}{|c|}{ Number of seeds pod ${ }^{-1}$} & \multicolumn{4}{|c|}{ Pod yield plant $^{-1}(\mathrm{~g})$} \\
\hline & Pinching & $\begin{array}{l}\text { Without } \\
\text { pinching }\end{array}$ & $\begin{array}{c}\text { Spray of } \\
\text { cycocel } \\
@ 75 \\
\text { ppm }\end{array}$ & Mean & Pinching & $\begin{array}{l}\text { Without } \\
\text { pinching }\end{array}$ & $\begin{array}{c}\text { Spray of } \\
\text { cycocel } \\
@ 75 \\
\text { ppm }\end{array}$ & Mean & Pinching & $\begin{array}{l}\text { Without } \\
\text { pinching }\end{array}$ & $\begin{array}{c}\text { Spray of } \\
\text { cycocel } \\
@ 75 \\
\text { ppm }\end{array}$ & Mean & Pinching & $\begin{array}{l}\text { Without } \\
\text { pinching }\end{array}$ & $\begin{array}{c}\text { Spray of } \\
\text { cycocel } \\
\text { @ } 75 \\
\text { ppm }\end{array}$ & Mean \\
\hline $\begin{array}{l}\text { Foliar spray } \\
\text { with DAP } \\
2 \%\end{array}$ & 25.6 & 20.8 & 21.7 & 22.7 & 23.9 & 24.5 & 23.8 & 24.1 & 33.2 & 34.8 & 34.5 & 34.2 & 277.07 & 269.31 & 239.25 & 261.88 \\
\hline $\begin{array}{l}\text { Foliar spray } \\
\text { with MN } \\
\text { Mixture } \\
\text { (ZnSO4 } \\
0.5 \%+ \\
\text { Boric acid } \\
0.3 \% \text { ) }\end{array}$ & 31.2 & 27.3 & 23.0 & 27.2 & 22.9 & 24.3 & 24.5 & 23.9 & 31.9 & 34.8 & 34.7 & 33.8 & 285.88 & 252.40 & 253.31 & 263.86 \\
\hline $\begin{array}{l}\text { Foliar spray } \\
\text { with NAA } \\
40 \mathrm{ppm}\end{array}$ & 28.7 & 23.6 & 22.1 & 24.8 & 24.4 & 24.0 & 24.5 & 24.3 & 33.7 & 33.3 & 35.5 & 34.2 & 331.33 & 244.11 & 223.68 & 266.37 \\
\hline $\begin{array}{l}\text { Foliar spray } \\
\text { with DAP } \\
2 \%+\text { MN } \\
\text { Mixture (Zn } \\
+ \text { B) + } \\
\text { NAA }\end{array}$ & 26.0 & 19.7 & 27.7 & 24.5 & 24.0 & 23.3 & 23.9 & 23.8 & 33.4 & 33.7 & 33.8 & 33.6 & 248.12 & 237.57 & 266.73 & 250.81 \\
\hline Control & 29.7 & 18.6 & 29.2 & 25.9 & 23.5 & 24.2 & 24.1 & 24.0 & 33.0 & 34.1 & 34.5 & 33.9 & 303.29 & 256.12 & 233.04 & 264.15 \\
\hline Mean & 28.2 & 22.0 & 24.7 & 25.0 & 23.7 & 24.1 & 24.2 & 24.0 & 33.0 & 34.1 & 34.6 & 33.9 & 289.14 & 251.90 & 243.20 & \begin{tabular}{|l|}
261.41 \\
\end{tabular} \\
\hline & S.Em \pm & S.Ed & C.D $(5 \%)$ & C.V. & S.Em \pm & S.Ed & C.D(5\%) & C.V. & S.Em \pm & S.Ed & C.D(5\%) & C.V. & S.Em & S.Ed & C.D $(5 \%)$ & C.V. \\
\hline Ai.-Aj. & 1.1 & 1.4 & 4.0 & 9.7 & 0.3 & 0.4 & N.S. & 2.6 & 0.3 & 0.5 & 1.3 & 2.8 & 17.0 & 24.0 & 66.90 & 14.48 \\
\hline Bi.-Bj. & 0.8 & 1.1 & 2.4 & & 0.2 & 0.3 & N.S. & & 0.3 & 0.4 & N.S. & & 12.6 & 17.8 & 36.84 & \\
\hline AiBi-AiBj & 1.4 & 2.0 & 4.1 & & 0.4 & 0.5 & 1.1 & & 0.5 & 0.8 & 1.6 & & 21.8 & 30.9 & 63.82 & \\
\hline $\mathrm{AiBi}-\mathrm{AjBi}$ & 1.6 & 2.3 & 5.4 & & 0.4 & 0.6 & 1.4 & & 0.6 & 0.8 & 1.9 & & 25.9 & 36.6 & 86.99 & \\
\hline
\end{tabular}


Table.2 Influence of pinching/cycocel and foliar nutrition on seed yield of dhaincha during Kharif, 2015-16

\begin{tabular}{|c|c|c|c|c|c|c|c|c|c|c|c|c|}
\hline \multirow[t]{2}{*}{ Treatments } & \multicolumn{4}{|c|}{ Seed yield plant $^{-1}(\mathrm{~g})$} & \multicolumn{4}{|c|}{ Seed yield ha ${ }^{-1}(q)$} & \multicolumn{4}{|c|}{ Seed recovery $(\%)$} \\
\hline & Pinching & $\begin{array}{l}\text { Without } \\
\text { pinching }\end{array}$ & $\begin{array}{c}\text { Spray of } \\
\text { cycocel } \\
@ 75 \\
\text { ppm }\end{array}$ & Mean & Pinching & $\begin{array}{l}\text { Without } \\
\text { pinching }\end{array}$ & $\begin{array}{c}\text { Spray of } \\
\text { cycocel } \\
@ 75 \\
\text { ppm }\end{array}$ & Mean & Pinching & $\begin{array}{l}\text { Without } \\
\text { pinching }\end{array}$ & $\begin{array}{c}\text { Spray of } \\
\text { cycocel } \\
\text { @ } 75 \\
\text { ppm }\end{array}$ & Mean \\
\hline Foliar spray with DAP 2\% & 170.11 & 166.76 & 148.59 & 161.82 & 21.58 & 22.95 & 24.19 & 22.91 & 62.1 & 61.6 & 62.2 & 61.9 \\
\hline $\begin{array}{l}\text { Foliar spray with MN Mixture } \\
(\mathrm{ZnSO} 40.5 \%+\text { Boric acid } 0.3 \%)\end{array}$ & 198.31 & 164.37 & 141.98 & 168.22 & 25.78 & 22.05 & 27.98 & 25.27 & 69.3 & 64.5 & 57.1 & 63.6 \\
\hline Foliar spray with NAA 40 ppm & 217.15 & 152.13 & 133.07 & 167.46 & 23.95 & 21.13 & 24.96 & 23.35 & 64.6 & 62.0 & 60.0 & 62.2 \\
\hline $\begin{array}{l}\text { Foliar spray with DAP } 2 \%+\mathrm{MN} \\
\text { Mixture }(\mathrm{Zn}+\mathrm{B})+\mathrm{NAA}\end{array}$ & 171.94 & 155.71 & 171.08 & 166.24 & 23.64 & 14.09 & 18.72 & 18.82 & 58.1 & 66.3 & 64.1 & 62.8 \\
\hline Control & 178.95 & 155.81 & 155.24 & 158.07 & 25.32 & 21.56 & 15.79 & 20.89 & 59.6 & 56.7 & 66.9 & 61.1 \\
\hline Mean & 187.29 & 155.81 & 149.99 & 164.36 & 24.05 & 20.35 & 22.3 & 22.24 & 62.7 & 62.2 & 62.1 & 62.3 \\
\hline & S.Em \pm & S.Ed & C.D(5\%) & C.V. & S.Em \pm & S.Ed & C.D(5\%) & C.V(\%) & S.Em \pm & S.Ed & C.D(5\%) & C.V \\
\hline Ai.-Aj. & 8.10 & 11.46 & 31.83 & 18.26 & 0.49 & 0.69 & 1.93 & 10.20 & 0.6 & 0.8 & N.S. & 12.4 \\
\hline Bi.-Bj. & 10.00 & 14.15 & 29.21 & & 0.75 & 1.06 & 2.20 & & 2.6 & 3.7 & N.S. & \\
\hline $\mathrm{AiBi}-\mathrm{AiBj}$ & 17.33 & 24.51 & 50.59 & & 1.30 & 1.85 & 3.82 & & 4.5 & 6.4 & N.S. & \\
\hline AiBi-AjBi & 17.49 & 25.74 & 54.85 & & 1.27 & 1.79 & 3.90 & & & 4.1 & 5.7 & N.S. \\
\hline
\end{tabular}

Table.3 Influence of pinching/cycocel and foliar nutrition on test weight (g) of dhaincha during Kharif, 2015-16

\begin{tabular}{|c|c|c|c|c|c|c|c|c|}
\hline \multirow[t]{2}{*}{ Treatments } & \multicolumn{4}{|c|}{100 seed weight $(\mathrm{g})$ - first picking } & \multicolumn{4}{|c|}{100 seed weight $(\mathrm{g})$ - second picking } \\
\hline & Pinching & $\begin{array}{l}\text { Without } \\
\text { pinching }\end{array}$ & $\begin{array}{l}\text { Spray of cycocel } \\
\text { @ } 75 \mathrm{ppm}\end{array}$ & Mean & Pinching & $\begin{array}{l}\text { Without } \\
\text { pinching }\end{array}$ & $\begin{array}{l}\text { Spray of cycocel } \\
\text { @ } 75 \text { ppm }\end{array}$ & Mean \\
\hline Foliar spray with DAP $2 \%$ & 2.02 & 2.01 & 2.22 & 2.08 & 2.10 & 2.15 & 2.12 & 2.13 \\
\hline $\begin{array}{l}\text { Foliar spray with MN Mixture (ZnSO4 } 0.5 \%+\text { Boric acid } \\
0.3 \%)\end{array}$ & 2.00 & 2.05 & 2.25 & 2.10 & 2.15 & 2.23 & 2.15 & 2.18 \\
\hline Foliar spray with NAA $40 \mathrm{ppm}$ & 2.05 & 2.02 & 2.22 & 2.10 & 2.11 & 2.15 & 2.04 & 2.10 \\
\hline Foliar spray with DAP $2 \%+$ MN Mixture $(\mathrm{Zn}+\mathrm{B})+\mathrm{NAA}$ & 2.07 & 1.92 & 2.14 & 2.04 & 2.13 & 2.20 & 2.19 & 2.17 \\
\hline Control & 2.08 & 2.01 & 2.19 & 2.09 & 2.06 & 2.21 & 2.09 & 2.12 \\
\hline Mean & 2.04 & 2.00 & 2.20 & 2.08 & 2.11 & 2.19 & 2.12 & 2.14 \\
\hline & $\mathbf{S . E m} \pm$ & S.Ed & C.D $(\mathbf{P}=\mathbf{0 . 0 5})$ & C.V(\%) & S.Em \pm & S.Ed & C.D $(P=0.05)$ & C.V(\%) \\
\hline Ai.-Aj. & 0.21 & 0.03 & 0.09 & 4.71 & 0.01 & 0.02 & 0.05 & 5.00 \\
\hline Bi.-Bj. & 0.03 & 0.05 & 0.10 & & 0.03 & 0.05 & 0.10 & \\
\hline $\mathrm{AiBi}-\mathrm{AiBj}$ & 0.06 & 0.08 & N.S. & & 0.06 & 0.09 & 0.18 & \\
\hline AiBi-AjBi & 0.06 & 0.08 & N.S. & & 0.06 & 0.08 & 0.16 & \\
\hline
\end{tabular}


Fig.1 Influence of pinching/cycocel on number of pods plant ${ }^{-1}$ of dhaincha during Kharif, 2015

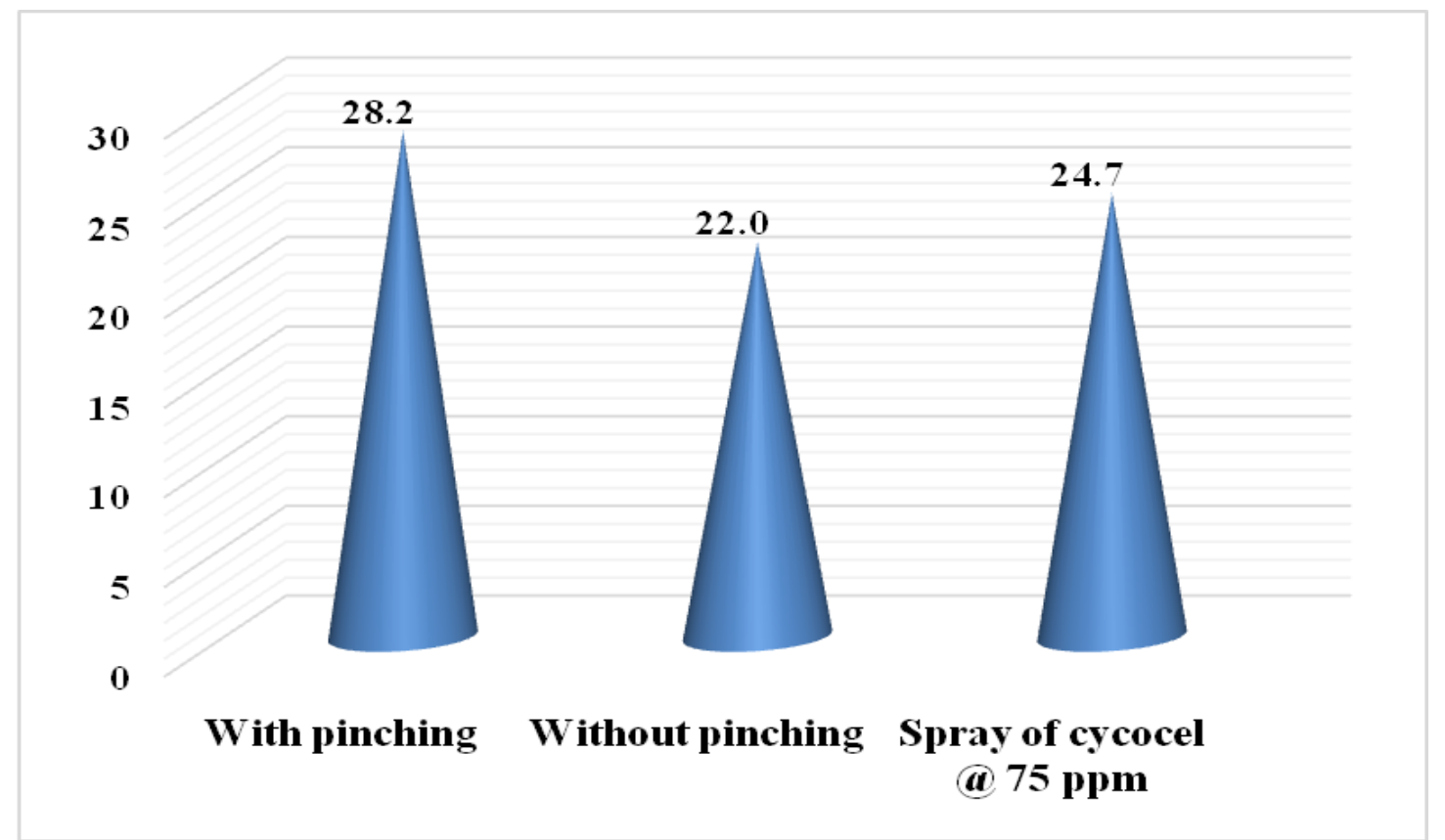

Fig.2 Influence of pinching/cycocel on seed yield ha ${ }^{-1}$ (q) of dhaincha during Kharif, 2015

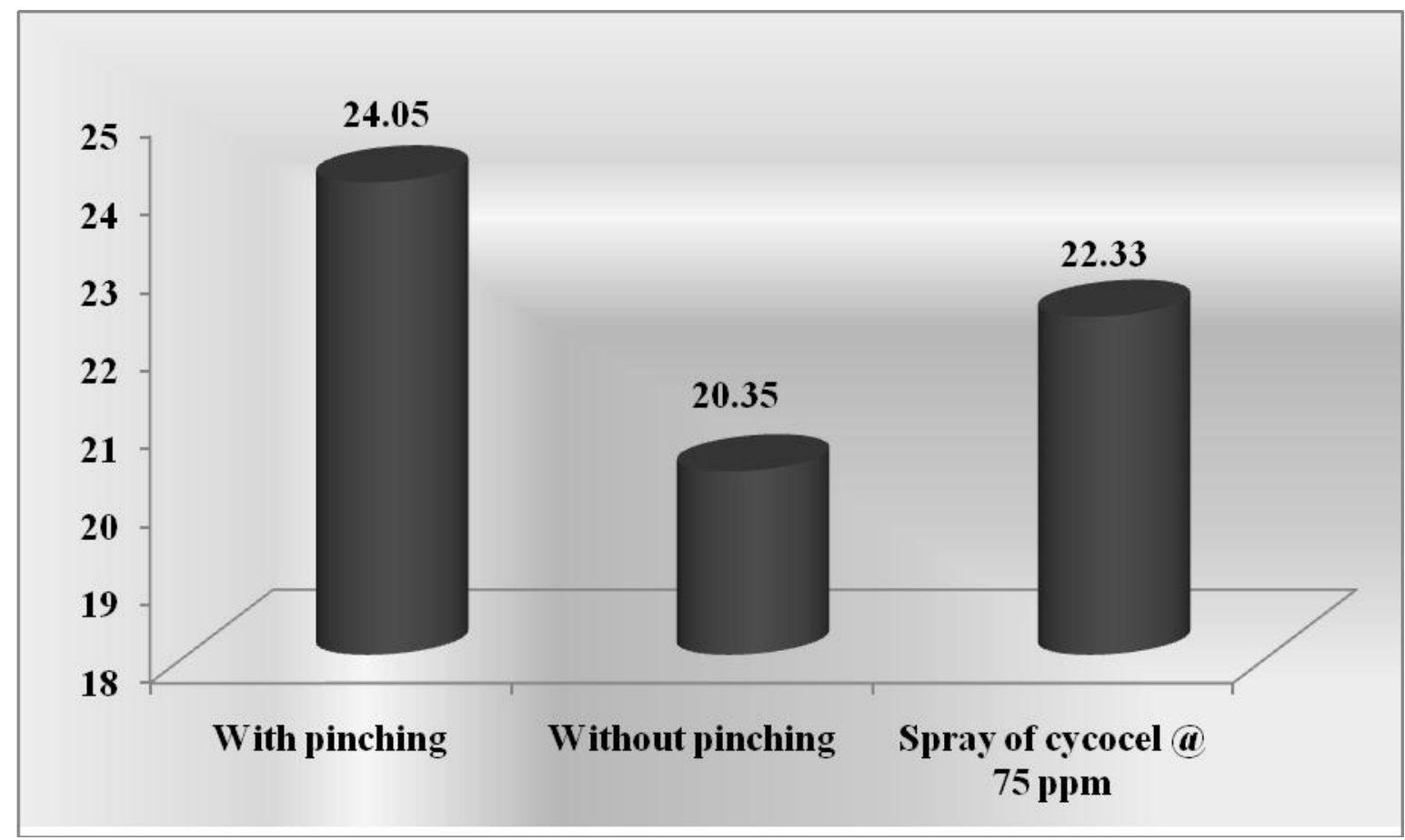

Among the interaction effects, the treatment pinching and foliar application of NAA @ 40 ppm recorded maximum pod yield $(331.33 \mathrm{~g})$ followed by pinching + without any foliar nutrition $(303.29 \mathrm{~g})$ and it was statistically on par with pinching + foliar spray with micronutrient mixture $\mathrm{ZnSO}_{4} 0.5 \%+$ Boric acid $0.3 \%,(285.88 \mathrm{~g})$ and pinching + foliar 
spray with DAP 2\% (277.07 g). However, it was on par with pinching + foliar spray with DAP $2 \%+$ micronutrient mixture $(\mathrm{Zn}+\mathrm{B})+$ NAA $(248.12 \mathrm{~g})$. With rest of the interaction effects it was significantly different from without pinching + foliar spray with NAA @ 40 ppm (244.11 g), without pinching + foliar spray with DAP 2\% + micronutrient mixture $(\mathrm{Zn}+\mathrm{B})+\mathrm{NAA}(237.57 \mathrm{~g})$, spray of cycocel @ $75 \mathrm{ppm}+$ foliar nutrition with DAP 2\% $(239.25 \mathrm{~g})$, spray of cycocel @ 75 ppm + foliar spray with NAA 40 ppm (233.68 g) and foliar spray of cycocel @ 75 ppm + without any foliar nutrition $(233.04 \mathrm{~g})$.

\section{Seed yield plant $^{-1}(\mathrm{~g})$}

Increased seed yield plant $^{-1}$ was observed with pinching $(187.29 \mathrm{~g})$ and was significantly superior over foliar spray with cycocel @ 75 ppm (149.99 g) and without pinching (155.81 g). Apical topping breaks the apical dominance and induces development of lateral branches thereby increasing the sites for pod development. The practice of topping has proved to be effective in increasing the yield levels of different crops like jute (Bhattacharjee and Mitra, 1999) and Indian mustard (Singh et al., 2013). Observed yield advantage in response to the removal of buds and younger leaves may be attributed to the prolonged canopy life of the plant which enables the plant to produce adequate photo assimilates for an extended period.

Among the sub plots, foliar spray with micro nutrient mixture $\mathrm{ZnSO}_{4} 0.5 \%+$ Boric acid $0.3 \%$ resulted in maximum seed yield plant $^{-1}$ $(168.22 \mathrm{~g})$ and it was statistically different from other three foliar sprays and control.

Interaction effect of dhaincha crop as influenced by pinching and foliar sprays indicated that pinching + foliar spray with NAA @ 40 ppm (217.15 g) was found superior for seed yield plant $^{-1}$ and it was significantly different from other interaction effects involving the other two main treatments i.e. without pinching and foliar spray of cycocel @ 75 ppm except foliar spray of cycocel @ 75 ppm + foliar spray with DAP 2\% + micronutrient mixture $(\mathrm{Zn}+$ B) + NAA treatment.

Seed yield $\mathrm{ha}^{-1}(\mathbf{q})$

Yield is the ultimate economic produce of the crop which is determined by number of pods, seed weight as governed by the management practice and its native genetic potential. Increased seed yield was recorded with pinching treatment $\left(24.05 \mathrm{q} \mathrm{ha}^{-1}\right)$ and was significantly higher than with spray of cycocel @ 75 ppm (22.33 q ha $\left.{ }^{-1}\right)$ and without pinching (20.35 q ha $\left.{ }^{-1}\right)$ treatments. Though spray of cycocel recorded reduced seed yield $\mathrm{ha}^{-1}$, it was significantly different from without pinching (20.35 q ha ${ }^{-1}$ ) treatment (Fig. 2). The per cent increase in seed yield noticed with pinching was $15.38 \%$ over control and 7.70\% over cycocel spray @ 75 ppm. The maximum yield observed under the effect of pinching might be attributed to growth characteristics which resulted in considerable improvement in yield attributing characters like pods plant ${ }^{-1}$ and seed yield plant $^{-1}$ and finally reflected into yield.

Further, more branches plant ${ }^{-1}$ under pinching treatment might have had multiplicative effect on seed yield. The increase in seed yield recorded with un pinched plants may be attributed to diversion of photosynthates and metabolites produced by leaves to strong carbohydrate sinks (pods) when compared to meristem in un pinched plants (Tripathi et al., 2013). The results are in confirmity with the findings of Bhattacharjee and Mitra (1999) and Jagannatham et al., (2008) in Mesta, Lakshmi et al., (1995) in Mesta, Kathiresan Duraisamy (2001) in Sesbania. 
Among different foliar applications, maximum seed yield ha ${ }^{-1}\left(25.27 \mathrm{q} \mathrm{ha}^{-1}\right)$ was recorded with foliar spray with micronutrient mixture $\mathrm{ZnSO}_{4} 0.5 \%$ + Boric acid $0.3 \%$ followed by foliar spray with NAA $40 \mathrm{ppm}$ $\left(23.35 \mathrm{q} \mathrm{ha}^{-1}\right)$. They were statistically on par with the other two foliar sprays i.e. control and foliar spray with DAP 2\% (22.91 q ha $\left.{ }^{-1}\right)$, foliar spray with DAP $2 \%+$ micronutrient mixture $(\mathrm{Zn}+\mathrm{B})+\mathrm{NAA}\left(18.82 \mathrm{q} \mathrm{ha}^{-1}\right)$ and without any foliar nutrition $\left(20.89 \mathrm{q} \mathrm{ha}^{-1}\right)$. The superiority in performance might be attributed to the prolonged assimilation activity of leaves thereby ensuring a considerable yield advantage (Vasilas et al., 1980).

Further, the foliage applied nutrients at the critical stages of the crop were effectively absorbed by the plant and translocated to the developing pods, producing more number of pods, more filling and higher yield. Significant improvement in seed yield with spray of secondary nutrients like sulphur, micronutrients like zinc and boron indicate that these nutrients play an important role in several enzymatic processes and are necessary for growth and development of the crop. They further contribute to increased branches, pods and seed yield. This could be attributed to the fact that boron plays an important role in cell division, cell differentiation, development, calcium utilization, translocation of photosynthates and growth regulators from source to sink, and help in maintaining higher leaf area, leaf area index and higher number of pods plant ${ }^{-1}$ (Kalyani et al.,1993). It also helps in preventing flower drop, pod drop and there by maintaining higher number of pods plant $^{-1}$

Among the interaction effects due to pinching and foliar applications, spray of cycocel @ 75 ppm + foliar application of micronutrient mixture $\left(\mathrm{ZnSO}_{4} 0.5 \%\right.$ + Boric acid 0.3\%) recorded maximum seed yield $\left(27.98 \mathrm{q} \mathrm{ha}^{-1}\right)$ and it was significantly different from other foliar sprays involving the same main treatment i.e. foliar spray with DAP $2 \%$ $\left(24.19 \mathrm{q}^{-1}\right)$, foliar spray with DAP $2 \%+$ micronutrient mixture $(\mathrm{Zn}+\mathrm{B})+\mathrm{NAA}$ $\left(18.72 \mathrm{q} \mathrm{ha}^{-1}\right)$ and control $\left(20.89 \mathrm{q}^{-1}\right)$.

\section{0 seed weight - First picking (g)}

An increase in 100 seed weight of dhaincha was observed with foliar spray of cycocel @ $75 \mathrm{ppm}(2.20 \mathrm{~g})$ and it was significantly superior to without pinching $(2.00 \mathrm{~g})$ and with pinching $(2.04 \mathrm{~g})$ treatments. These results are in conformity with the findings of Pourmohammad et al., (2014) who reported significant increase in 1000 seed weight with foliar spray of cycocel. Other workers Tomar et al., (2004), Bhat and Shepherd (2007) observed significant reduction in 1000 seed weight due to pinching treatment. Reduction in individual flower size and weight under pinching might have produced smaller seeds which in turn might have reduced the 1000 seed weight. However, Mohanthy et al., (2015) and Sunitha et al., (2007) in African marigold observed that seed weight was higher in pinching treatment compared to no pinching. On the other hand, Tripathi et al., (2013) reported non-significant difference in test weight of sunhemp due to topping.

Among the sub plots, the treatment foliar spray with micronutrient mixture $\left(\mathrm{ZnSO}_{4}\right.$ $0.5 \%$ + Boric acid $0.3 \%$ ) recorded maximum seed weight of $2.10 \mathrm{~g}$ and it was statistically on par with the other three foliar sprays and control indicating that application of foliar nutrients did not have any significant impact on increasing the seed weight. These results are in agreement with the findings of Elamathi and Pradeep, (2007) and Nigamananda and Elamathi (2007) in green gram.

Interaction effect as influenced by pinching and foliar sprays showed that spray of cycocel 
@ $75 \mathrm{ppm}+$ foliar nutrition with micronutrient mixture $\left(\mathrm{ZnSO}_{4} 0.5 \%+\right.$ Boric acid $0.3 \%$ ) recorded maximum 100 seed weight of $2.25 \mathrm{~g}$ and it was statistically at par with spray of cycocel @ 75 ppm at peak flowering stage in combination with different foliar applications. However, it was significantly different from other interaction effects involving both pinching and without pinching treatments.

\section{0 seed weight - Second picking (g)}

Data pertaining to 100 seed weight of the produce obtained from second picking of dhaincha crop as influenced by pinching/cycocel spray and foliar nutrition is depicted in Table 3. An increase in 100 seed weight of dhaincha was observed with without pinching treatment $(2.19 \mathrm{~g})$ and it was significantly superior over the treatments foliar spray of cycocel @ 75 ppm $(2.12 \mathrm{~g})$ and without pinching $(2.11 \mathrm{~g})$. In general, seed weight of the produce obtained from second picking $(2.13 \mathrm{~g})$ was bold compared to the seed realized from first picking $(2.08 \mathrm{~g})$. Highest seed weight of $2.18 \mathrm{~g}$ was observed with foliar spray with micronutrient mixture $\left(\mathrm{ZnSO}_{4} 0.5 \%+\right.$ Boric acid $\left.0.3 \%\right)$ and was statistically on par with other foliar sprays i.e. foliar spray with DAP 2\% (2.13 g), foliar spray with NAA 40 ppm (2.10 g), foliar spray with DAP $2 \%+$ micronutrient mixture $(\mathrm{Zn}+$ B) + NAA (2.17 g) and control (2.12 g). Bold seeds recorded with foliar application of $\mathrm{Zn}, \mathrm{S}$ and boron might be due to boron which played a pivotal role in translocation of assimilates to developing sink (Elamathi and Pradeep 2007).

Interaction effect of 100 seed weight revealed that the treatment i.e. without pinching and foliar spray with micronutrient mixture $\left(\mathrm{ZnSO}_{4} 0.5 \%+\right.$ Boric acid $\left.0.3 \%\right)$ recorded maximum 100 seed weight of $2.23 \mathrm{~g}$ and it was statistically on par with other foliar applications. However, it was significantly different from the treatments $\mathrm{M}_{1} \mathrm{~S}_{5}$ i.e. pinching + without any foliar nutrition (2.06 g) and pinching + foliar spray with NAA 40 ppm $(2.04 \mathrm{~g})$.

\section{References}

Ahmad, I., Khurram, Z.M., Qasim and Tariq, M. 2007. Comparative evaluation of different pinching approaches on vegetative and reproductive growth of carnation (Dianthus caryophyllus). Pakistan Journal Agricultural Science. 44(4): 69-73.

Ajay Kumar, M., Sudip, D and Roy. 2014. Effect of different growth regulators and phosphorus levels on nodulation, yield and quality components in green gram. Indian Journal of Plant Physiology. 19(1): 74-78.

Bhat, Z. A., and Shepherd, H. 2007. Effect of pinching on growth, flowering, seed yield and quality traits in African marigold (Tagets erecta Linn.). Journal of Ornamental Horticulture. 10(3): 197198.

Bhattacharjee, A.K., and Mitra, B.N. 1999. Jute seed productivity and its quality as influenced by suppression of apical dominance. In Palit et al., (eds.) Jute and Allied Fibres: Agriculture and Processing, CRIJAF Publication, India. 117-185.

Cakmak, I., Marschner, $\mathrm{H}$ and Bangerth, F. 2000. Effect of zinc nutritional status on growth, protein metabolism and levels of indole-3 acetic acid and other phytohormones in bean. Journal of Experimental Botany. 40(1): 405-408.

Devi, K. N., Vyas, A.K., Maibam, S.S and Naorem, G.S. 2011. Effect of bioregulators on growth, yield and chemical constituents of soybean (Glycine max). Journal of Agriculture Sciences. 3: 151-159. 
Elamathi, S., and Pradeep, M.D. 2007. Effect of foliar application of DAP, micronutrients and NAA on growth and yield of green gram (Vigna radiata $\mathrm{L}$.). Legume Research. 30(4): 305-307.

FAI 2007-08. Fertilizer Association of India. Fertilizer Statistics. II-63.

Ganiger T.S., Kareekatti, S.R and Patil B.C. 2002. Effect of plant growth regulators on growth and yield in cowpea. Karnataka Journal Agricultural Sciences. 15(4): 701-704.

Hossain, M.A., Focken, U and Becker, K. 2001. Galactomannan rich endosperm of Sesbania (Sesbania aculeata) seed responsible for retardation of growth and feed utilization of common carp, (Cyprinus caprio L.). Aquaculture. 203: 121-123.

Jagannatham, J., Rajendra, K.B., Sreelatha, T and Rajabapa, R.V. 2008. Effect of topping on seed yield and fibre yield of mesta, sabdariffa vs. cannabinus. In: Palit et al., (eds.) Abstracts of papers: International Symposium on Jute and Allied Fibres Production, Utilization and Marketing held at Kolkata, India. CRIJAF, Publication. 121.

Jayaram, R., and Ramaiah S. 1980. Response of cowpea (Vigna sinensis L.) to phosphours and growth regulators. Madras Agricultural Journal. 67(2): 102-105.

Kalyani, R., Ratna Devi, V., Satyanarayana, N.V., Rao, S and Madhava Rao, K.V. 1993. Effect of foliar application of boron on crop growth and yield of pigeon pea. Indian Journal of Plant Physiology. 36(4): 223-226.

Kathiresan, G., and Duraisamy, K. 2001. Effect of clipping and diammonium phosphate spray on growth and seed yield of dhaincha (Sesbania aculeata). Journal of Agronomy. 46(2): 568-572.

Lakshmi, M.B., Naidu, M.V., Reddy, D.S and Reddy, C.V. 1995. Effect of time of sowing and topping on seed yield of Mesta. Indian Journal of Agronomy. 40(4): 682-685.

Mohanty, C.R., Mohanty, A and Parhi, R. 2015. Effect of planting dates and pinching on seed traits in African marigold cv. Sirakole. Agricultural Science Diges. 35(4): 285-289.

Nigamananda, B., and Elamathi, S. 2007. Studies on the time of nitrogen application, foliar spray of DAP and growth regulator on yield attributes, yield and economics of green gram (Vigna radiata L.). International Journal of Agricultural Sciences. 3(1): 168-169.

Parlawar, N.D., Giri, D.G. and Adpawar, R.M. 2003. Influence of seed rate, row spacing and phosphate level on nutrient uptake in Dhaincha. Journal of Soils and Crops. 13(2): 364-367.

Parmar, V.K., Dudhatra, M.G and Thesiya, N.M. 2012. Effect of growth regulators on growth characters of summer green gram. Legume Research. 35: 81-82.

Pathania, N.S., Sehgal, O.P and Gupta, Y.C. 2000. Pinching for flower regulation in sim carnation. Journal of Ornamental Horticulture. 3: 114-117.

Pourmohammad, V., Shekari, F and Soltaniband, V. 2014. Cycocel priming and foliar application affect yield components of rapeseed (Brassica napus L.). Agronomical Research in Moldavia. 2(1): 157-158.

Raghava, N., Kumar, P and Raghava, 1996. Leaf growth, nodulation and yield performance in cowpea as influenced by growth regulators. Plant Physiology and Biochemistry. 23: 85-89.

Reddy, P., B. Ninganur, B. T., Chetti M. B and Hiremath, S. M. 2009. Effect of growth retardants and nipping on chlorophyll content, nitrate reductase activity, seed protein content and yield in cowpea (Vigna unguiculata L.). 
Karnataka Journal of Agricultural Sciences. 22(2): 289-292.

Seifinadergholi, M., Yarnia, M and Rahimzade, KF. 2011. Effect of zinc and management and their application method on yield and yield components of common bean. Middle-East Journal of Science and Research. 8(5):859-865.

Sharma S.C., and Dey, S.C. 1986. Foliar application of macro and micronutrients and NAA on growth and yield of green gram (Vigna radiata L.). Legume Research.13: 71-74.

Singh, B., Satyavir, S., Vinod, $\mathrm{K}$ and Yogender, K. 2013. Nitrogen and nipping schedule for higher productivity of sesame (Sesamum indicum L.) on aridisols of South-Western Haryana. Haryana Journal of Agronomy. 29(1-2): 1-5.

Sunitha, H.M., Ravi, H., Vyakaranahal, B.S and Bablad, H.B. 2007. Effect of pinching and growth regulators on plant growth, flowering and seed yield in African marigold (Tagetes erecta Linn.). Journal of Ornamental Horticulture. 10(2): 91-95.

Tomar, B.S., Singh, B., Negi, H.C and Singh, K.K. 2004. Effect of pinching on seed yield and quality traits in African marigold. Journal of Ornamental Horticulture. 7(4): 232-233.

Tripathi, M. K., Chaudhary, B., Singh, S.R and Bhandari, H.R. 2013. Growth and yield of sunhemp (Crotalaria juncea $\mathrm{L}$.) as influenced by spacing and topping practices. African Journal of Agricultural Research. 2(28): 37443749.

Vasilas, B.L., Legs, J.O and Wolf, D.C. 1980. Foliar fertilization of soybeans. Absorption and translocation of $15-\mathrm{N}$ labeled urea. Agronomy Journal. 72: 271-275.

\section{How to cite this article:}

Hari Nayak, K. Kanaka Durga, V. Bharathi and Keshavulu, K. 2017. Evaluation of Different Pinching Approaches on Seed Yield in Dhaincha. Int.J.Curr.Microbiol.App.Sci. 6(10): 898909. doi: https://doi.org/10.20546/ijcmas.2017.610.108 